\title{
Inventory and Protection of Salt Marshes from Risks of Sea-Level Rise at Acadia National Park, Maine
}

Recent U.S. Geological Survey (USGS) climate studies in the northeastern United States have shown substantial evidence of climate-related changes during the last 100 years, including earlier snowmelt runoff, decreasing occurrence of river ice, and decreasing winter snowpack. These studies related to climate change are being expanded to include investigation of coastal wetlands that might be at risk from sealevel rise. Coastal wetlands, particularly salt marshes, are important ecosystems that provide wildlife nursery and breeding habitat, migratory bird habitat, water quality enhancement, and shoreline erosion control. The USGS is investigating salt marshes in Acadia National Park with the goal of determining which salt marshes may be threatened by sea-level rise and which salt marshes may be able to adapt to sea-level rise by migrating into adjacent low-lying lands.

\section{Background}

Salt marshes are an important part of the landscape of Acadia National Park. In addition to their aesthetic beauty, they provide significant ecological value to Maine's coastal zone (fig. 1). Their ecological functions include habitat for many fish and wildlife species; tremendous organic matter production that fuels coastal food webs, including many commercially and recreationally valuable species; storm and flood protection; and filtration of nutrients, sediments, and contaminants from waters entering the coastal zone.

Salt marshes form and grow close to sea level under special conditions that provide intermittent exposure to saltwater and vertical development through the supply and accumulation of mineral sediment and plant organic matter. As the plants grow, the roots and rhizomes, along with sediment and organic matter, form peat, the foundation of the marsh. To keep up with rises in sea level, the elevation of salt marsh surfaces must increase through a combination of sediment accumulation and peat growth (Cahoon and others, 1999).

Historically, sea level has risen in New England at rates ranging from 0.6 to 2.5 millimeters per year $(\mathrm{mm} / \mathrm{yr})(0.02$ to 0.10 inches per year (in/yr)) over the last 100 years (Woodworth and Player,
2003; Kirshen and others, 2008), whereas Maine salt marshes have been found to accrete surface sediment at rates of up to $4.2 \mathrm{~mm} / \mathrm{yr}$ ( $0.17 \mathrm{in} / \mathrm{yr}$ ) (Goodman and others, 2007). Many New England marshes have been able to adapt to historical changes in sea level by accretion of new sediment and organic matter and through subsurface peat growth (Cahoon and others, 2009; Goodman and others, 2007).

The rate of sea-level rise, however, is expected to accelerate significantly in the next century; this acceleration is a projected global effect of climate warming caused by melting polar ice and expansion of the ocean because of warming waters (NECIA, 2006). Projected rates of sea-level rise are as high as $8.4 \mathrm{~mm} / \mathrm{yr}(0.33 \mathrm{in} / \mathrm{yr})$ (Kirshen and others, 2008). This rate of sea-level rise could be greater than the rates of vertical elevation gain in salt marshes, putting them at risk of frequent flooding by saltwater, changes in sediment supply, changes in salinity, and changes in storm intensity and wave action (Cahoon and others, 2009). Projections of total sea-level rise range from 200 to $1,000 \mathrm{~mm}(0.7$ to 3.3 feet $(\mathrm{ft}))$ by the year 2100 (NECIA, 2006; IPCC, 2007).

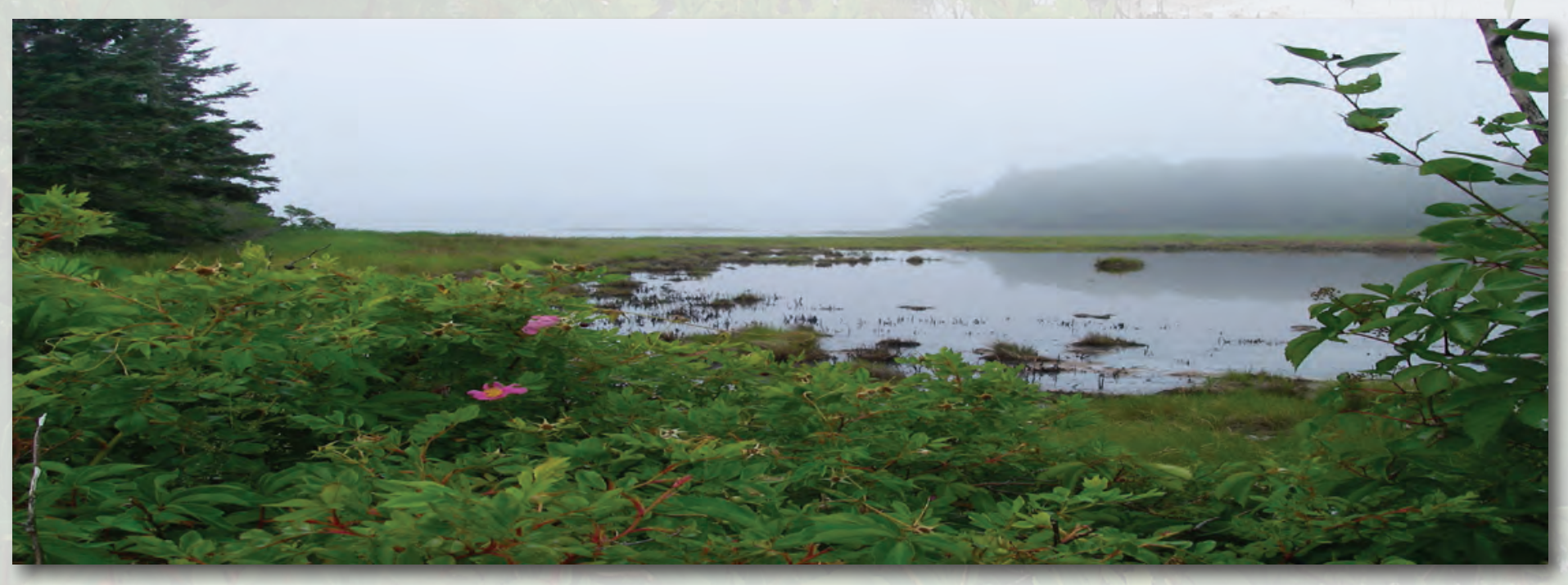

Figure 1. Salt marsh on Deer Isle, Maine. (Photograph by Robert Dudley, U.S. Geological Survey, July 13, 2010). 


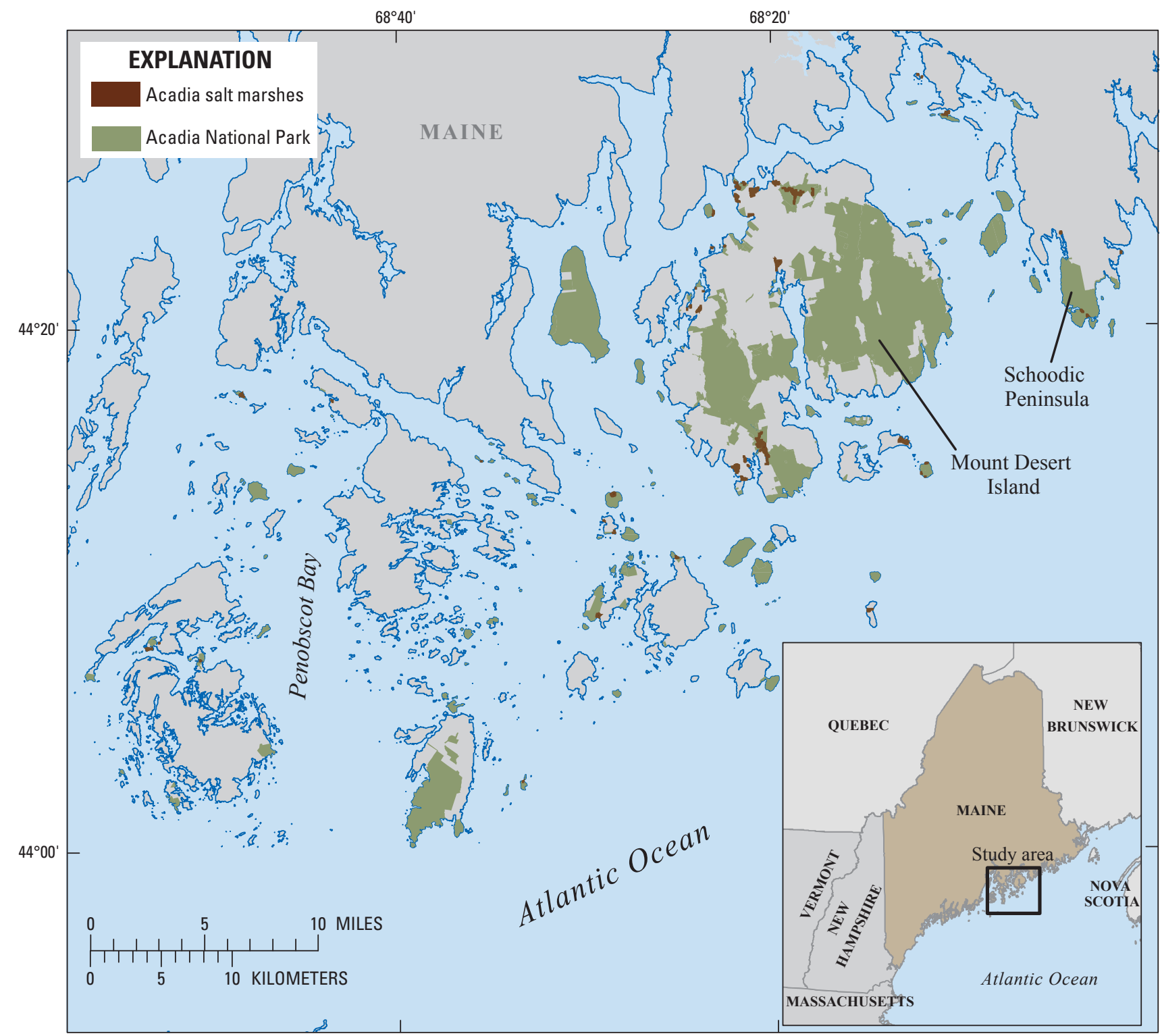

Base map from USGS 1:24,000 Digital Line Graphs. Acadia National Park

Boundary from National Park Service, 1:24,000

Figure 2. Distribution of salt marshes near Acadia National Park, Maine.

Although there is great uncertainty in the precise amount of sea-level rise, a rise of $600 \mathrm{~mm}(2.0 \mathrm{ft})$ by 2100 has been projected for Maine (see, for example, Slovinsky and Dickson, 2006).

If the rates of accretion of existing salt marshes cannot equal those of sea-level rise in some areas, the primary mechanism for salt marshes and the important habitat they offer to survive in the long term will be horizontal migration involving the formation of new salt marshes on newly flooded lands. The identification and protection of adjacent low-lying lands available for marsh migration are therefore important tasks to help ensure future salt marsh survival.
Equally important is the identification of barriers to the movement of salt marshes such as roads, dikes, and seawalls. In 2010, the USGS began a study with the National Park Service to identify the availability of low-lying areas near salt marshes in and around Acadia National Park and on islands from Penobscot Bay to the Schoodic Peninsula (fig. 2) and to evaluate the marshes for their potential to migrate into these adjacent areas under a projected $600-\mathrm{mm}(2.0 \mathrm{ft})$ rise in sea level.

\section{Study Approach}

Several approaches have been used in predicting the effect of sea-level rise on coastal habitats. Inundation models, also called static models, show where low-lying land adjacent to salt marshes will be submerged and where engineered structures may be threatened for an assumed amount of sea-level rise (see, for example, Slovinsky and Dickson, 2006). The best static models use the most accurate elevation data available, such as light detection and ranging (LiDAR) data, to delineate the areas that would be submerged under a given sea-level rise scenario (Gesch and others, 2009). LiDAR data are collected by flying over the area of interest and scanning the ground with pulsed laser light to accurately detect the elevation of the ground beneath (fig. 3). 
The average accuracy of groundelevation data collected by using LiDAR for this project is expected to be about $92.5 \mathrm{~mm}$ (3.64 in.). USGS scientists will assess the accuracy of LiDAR data specifically in the salt marshes of the study area (fig. 4). The USGS is working with the National Park Service and conservation partners such as the Maine Coast Heritage Trust to select salt marshes that will be used for the LiDAR data accuracy assessment. The elevations of 20 marshes will be determined by surveying marsh elevations in relation to independent stable control points for which precise elevations will be established by using high-accuracy Global Positioning System (GPS) equipment. Surveyed marsh eleva- tions will be used as a check against the LiDAR-derived elevations.

LiDAR elevation data were collected in the fall of 2010. Once the final processing of the LiDAR data has been done, a detailed map of all salt marshes in the study area will be overlain onto the LiDAR-derived land surface. Using this land-surface dataset, low-lying areas adjacent to existing salt marshes that could be expected to flood as a result of a $600-\mathrm{mm}(2.0 \mathrm{ft})$ rise in sea level and that could be suitable for salt marsh habitat (that is, not developed) will be identified. In addition, areas along the coastline that currently do not have salt marsh but would be protected and sheltered enough to sustain salt marsh ecosystems if they became flooded also will be identified.
USGS scientists also will identify any potential physical barriers (roads, berms, and bridges) to inland migration of salt marshes. The results of the accuracy assessment of the LiDAR data will be used to estimate confidence intervals for the prediction of areas with a potential to flood and possibly form new salt marsh.

\section{Benefits}

This project will inform the National Park Service and its conservation partners about which salt marshes in and around Acadia National Park might migrate into adjacent low-lying lands given future sealevel rise projections. Using this information, park managers can plan for additional land conservation into the future.

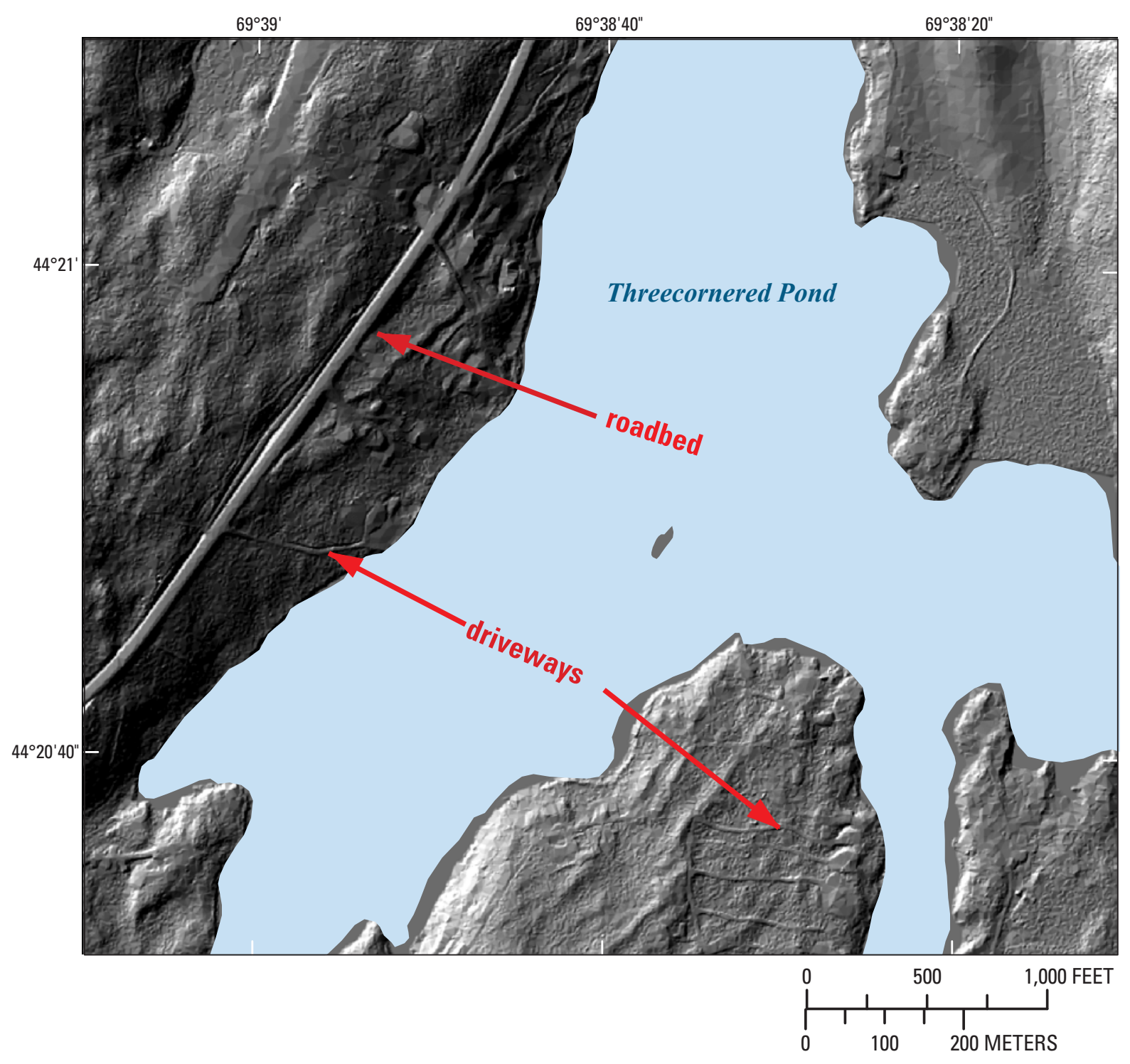

Figure 3. Example of LiDAR (light detection and ranging) data for Kennebec County, Maine. Note the accuracy of the LiDAR data such that roadbeds and driveways are visible. 


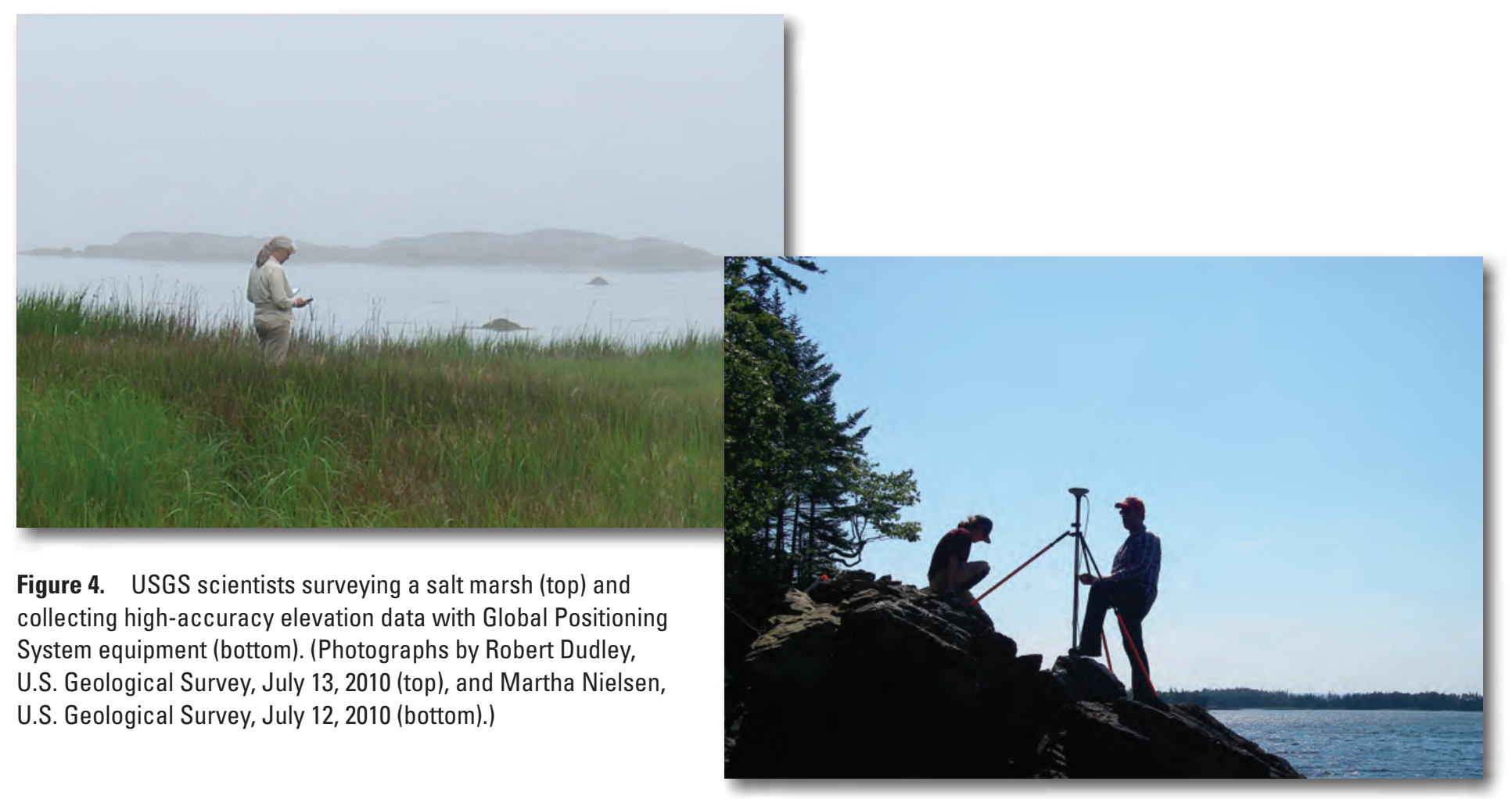

\section{References}

Cahoon, D.R., Day, J.W. Jr., and Reed, D.J., 1999, The influence of surface and shallow subsurface soil processes on wetland elevation-A synthesis: Current Topics in Wetland Biogeochemistry, v. 3, p. 72-88.

Cahoon, D.R., Reed, D.J., Kolker, A.S., Brinson, M.M., Stevenson, J.C., Riggs, S., Christian, R., Reyes, E., Voss, C., and Kunz, D., 2009, Coastal wetland sustainability, chap. 4 in Titus, J.G., coordinator, Coastal sensitivity to sea-level rise-A focus on the Mid-Atlantic region: A report by the U.S. Climate Change Science Program and the Subcommittee on Global Change Research, Washington, D.C., U.S. Environmental Protection Agency.

Gesch, D.B., Gutierrez, B.T., and Gill, S.K., 2009, Coastal elevations, chap. 2 in Titus, J.G., coordinator, Coastal sensitivity to sealevel rise-A focus on the Mid-Atlantic region: A report by the U.S. Climate Change Science Program and the Subcommittee on Global Change Research, Washington, D.C., U.S. Environmental Protection Agency.

Goodman, J.E., Wood, M.E., and Gehrels, W.R., 2007, A 17-year record of sediment accretion in the salt marshes of Maine (USA): Marine Geology, v. 242, p. 109-121.

IPCC (Intergovernmental Panel on Climate Change), 2007, Climate change 2007-The science basis, contribution of Working Group 1 to the Fourth Assessment Report: Cambridge, U.K., Cambridge University Press.

Kirshen, P., Watson, C., Douglas, E., Gontz, A., Lee, J., and Tian, Y., 2008, Coastal flooding in the Northeastern United States due to climate change: Mitigation and Adaptation Strategies for Global Change, v. 13, p. 437-451.

NEICA (Northeast Climate Impacts Assessment), 2006, Climate change in the U.S. Northeast: Cambridge, Mass., Union of Concerned Scientists, $35 \mathrm{p}$.

Slovinsky, P.A., and Dickson, S.M., 2006, Impacts of future sea level rise on the coastal floodplain: Maine Geological Survey OpenFile Report 06-14, 25 p.

Woodworth, P.L., and Player, R., 2003, The permanent service for mean sea level—An update to the 21st century: Journal of Coastal Research, v. 19, p. 287-295.

For more information, please contact Director

USGS Maine Water Science Center 196 Whitten Road Augusta, Maine 04330

Telephone: (207) 622-8201

E-mail: dc_me@usgs.gov

Web site: http://me.water.usgs.gov 